\title{
The Possibilities of a Gospel Codex: GA 2064 (Dublin, CBL W 139), Digital Editing, and Reading in a Manuscript Culture
}

\author{
GARRICK V. ALLEN \\ garrick.allen@glasgow.ac.uk \\ University of Glasgow, G12 8QQ, Glasgow, UK
}

\begin{abstract}
Recent changes to the technology used to produce critical editions and the mass digitization of Greek New Testament manuscripts are beginning to fundamentally alter the place of later manuscripts in critical practice, reinvigorating research into minuscules and particular subtraditions of manuscripts that have often stood outside the interest of most New Testament scholars. This situation necessitates a reexamination of often-overlooked manuscripts, going beyond traditional text-critical concerns to better understand the ways that manuscripts function as arbiters of knowledge for the texts they carry, especially when their paratextuality and design differ from modern Bibles and critical editions. Changes in editorial technology have created a situation where editions can also be informed by the conceptual networks of literary interrelationships and interpretive pathways reflected in the layout and design of manuscripts. Moreover, the expanded availability of digital manuscript images creates new avenues for interdisciplinary exploration of the significance of paratextual systems. This article begins to explore these issues by analyzing the unpublished GA 2604 (Dublin, CBL W 139), a deluxe twelfth-century gospel codex.
\end{abstract}

Manuscripts of all forms and from all periods provide reception-historical information about their producers, users, and contexts. ${ }^{1}$ This critical point has been

\footnotetext{
${ }^{1}$ See Thomas J. Kraus, “Ad fontes: Gewinn durch die Konsultation von Originalhandschriften am Beispiel von P.Vindob.G 31974,” Bib 82 (2001): 1-17, here 1: manuscripts show us the "fingerprints of a bygone era, which are fixed in the specific script or inscription and spelling of a manuscript" ("Fingerabdrücke einer vergangenen Zeit, die sich im jeweiligen Material, in der spezifischen Schrift bzw. Beschriftung und der Rechtschreibung eines Manuskripts verfestigt haben"). See also Garrick V. Allen, "Paratexts and the Reception History of the Apocalypse," JTS 70 (2019): 600-632.
} 
emphasized in recent decades in literary studies that explore the ways that artifacts in various media are expressive forms, focusing primarily on the physical dynamics of early print culture and how its nontextual features interact with texts to create meaning from their bibliographic and textual codes. ${ }^{2}$ The application of New Philology (or material philology) to literature first emerged in the context of early European vernacular literature, spearheaded by the bold critiques of textcritical practice by Bernard Cerquiglini, moving on later to Anglophone research contexts and the study of other ancient literatures. ${ }^{3}$ Although sometimes broached, this approach has not yet been fully appreciated in New Testament scholarship. ${ }^{4}$ The study of Greek New Testament manuscripts has focused primarily on papyri and early pandect codices, largely because of their antiquity and because they preserve states of texts that are valuable for textual reconstruction. But new forms of material philology have become all the more pressing for medieval and even early modern New Testament manuscripts due to the changes in media in our current context; the move to digital spaces and the digitization of cultural heritage have forced scholars to rethink what it is about both print and nontypographic materials that is worth encoding and representing in these spaces. This movement follows trends in literary studies that emphasize the material and contextual aspects of textual transmission as central to the ongoing life of a work and its reception. A good example is Stephen G. Nichols's digital edition of the Roman de la Rose, which

${ }^{2}$ See, e.g., Jerome McGann, Radiant Textuality: Literature after the World Wide Web (New York: Palgrave Macmillan, 2001); McGann, A New Republic of Letters: Memory and Scholarship in the Age of Digital Reproduction (Cambridge: Harvard University Press, 2014); D. F. McKenzie, Bibliography and the Sociology of Texts (Cambridge: Cambridge University Press, 1999); Roger Chartier, Forms and Meanings: Texts, Performances, and Audiences from Codex to Computer, New Cultural Studies (Philadelphia: University of Pennsylvania Press, 1995); N. Katherine Hayles, How We Think: Digital Media and Contemporary Technogenesis (Chicago: University of Chicago Press, 2012), among others.

${ }^{3}$ Bernard Cerquiglini, Éloge de la variante: Histoire critique de la philologie, Des travaux (Paris: Seuil, 1989). New Philology made its way into Anglophone scholarship through a special fascicle of the journal Speculum edited by Stephen G. Nichols. See Nichols, "Introduction: Philology in a Manuscript Culture," Speculum 65 (1990): 1-10. New Philology has always been received with mixed reviews, sometimes embedded in the same volume. See the many contradictory articles in Martin-Dietrich Gleßgen and Franz Lebsanft, eds., Alte und neue Philologie, Beihefte zu Editio 8 (Tübingen: Niemeyer, 1997), especially Albert Varvaro's critique of Cerquiglini in "La 'New Philology' nella prospettiva italiana," 35-42. For a recent overview of the history of New Philology, see Liv Ingeborg Lied and Hugo Lundhaug, eds., Snapshots of Evolving Traditions: Jewish and Christian Manuscript Culture, Textual Fluidity, and New Philology, TUGAL 175 (Berlin: de Gruyter, 2017), esp. 3-12.

${ }^{4}$ Exceptions exist within New Testament studies. For example, Thomas Kraus, "Manuscripts with the Lord's Prayer-They Are More than Simply Witnesses to That Text Itself," in New Testament Manuscripts: Their Texts and Their World, ed. Thomas J. Kraus and Tobias Nicklas, TENTS 2 (Leiden: Brill, 2006), 227-66; Garrick V. Allen, Manuscripts of the Book of Revelation: New Philology, Paratexts, Reception (Oxford: Oxford University Press, 2020).

This article was published in JBL 140/2 (2021) 409-434, copyright $\odot 2021$ by the Society of Biblical Literature. To purchase copies of this issue or to subscribe to JBL, please contact SBL Customer Service by phone at 866-727-9955 [toll-free in North America] or 404-727-9498, by fax at 404-727-2419, or visit the online SBL Store at www.sbl-site.org. 
provides access to the manuscripts it purports to represent and the paratextual and material complexities of that tradition. ${ }^{5}$

Understanding the ways that manuscripts organize access to their texts through their paratextuality is becoming increasingly relevant in biblical studies. ${ }^{6}$ We are rediscovering that the New Testament and other literary works transmitted in manuscript cultures are not disembodied texts and that the ways that manuscripts are designed create networks of possible readings, influencing engagement with their texts. Textual change and the technology of manuscript cultures go hand in hand. As Hugo Lundhaug and Liv Ingeborg Lied have noted, "our surviving witnesses constitute ... snapshots" and because "these snapshots are not necessarily representative of the entire movie, it is pertinent to approach the interpretation of these texts from a perspective inspired by New Philology, taking textual fluidity and manuscript culture fully into consideration."

Manuscripts create complexes of possible reading events by prescribing both linear and nonlinear forms of reading. The possible reading pathways of some manuscripts, like deluxe Byzantine gospel manuscripts with multiple cross-referencing systems, are almost infinite. And if we adopt the new philological perspective that all manuscripts are genuine instantiations of the works that they carry regardless of their utility for reconstructing an initial text, then we must, as biblical scholars, begin to explore the many complexities of one of the most well-preserved and widely transmitted manuscript traditions in existence.

If manuscripts bring important aspects of the tradition to the fore beyond their texts, then New Philology is relevant also for the ongoing production of New Testament editions, particularly those designed to function as digital objects. The Acts volume of the Editio Critica Maior (ECM), for example, was recently published by the Institut für Neutestamentliche Textforschung as a digital edition. ${ }^{8}$

${ }^{5}$ Stephen G. Nichols, From Parchment to Cyberspace: Medieval Literature in the Digital Age (New York: Lang, 2016), 1-14.

${ }^{6}$ I use the word paratext in this article to refer to all features of a manuscript beside the main text of its primary work, including items like titles, marginal notations, prefaces of various kinds, tables of contents and other lists, and cross-reference systems, among others. This term, coined initially by Gérard Genette (Paratexts: Thresholds of Interpretation, trans. Jane E. Lewin, Literature, Culture, Theory 20 [Cambridge: Cambridge University Press, 1997]), is used in different ways in the humanities generally and in biblical studies in particular. See Patrick Andrist, "Toward a Definition of Paratext and Paratextuality: The Case of Ancient Greek Manuscripts," in Bible as Notepad: Tracing Annotations and Annotation Practices in Late Antique and Medieval Biblical Manuscripts, ed. Liv Ingeborg Lied and Marilena Maniaci, Manuscripta Biblica 3 (Berlin: de Gruyter, 2018), 130-49; and Garrick V. Allen and Anthony P. Royle, "Paratexts seeking Understanding: Manuscripts and Aesthetic Cognitivism," Religions 11 (2020): 1-25.

${ }^{7}$ Hugo Lundhaug and Liv Ingeborg Lied, "Studying Snapshots: On Manuscript Culture, Textual Fluidity, and New Philology," in Lied and Lundhaug, Snapshots of Evolving Traditions, $1-19$, here 1.

${ }^{8}$ See http://ntvmr.uni-muenster.de/nt-transcripts. This edition is a developing workspace. 
And the attention of the editors of the Apocalypse volume in the ECM, in production at the Institut für Septuaginta- und biblische Textforschung at the Kirchliche Hochschule Wuppertal/Bethel, extends also to other paratextual information in the manuscripts. In addition to creating digital transcriptions of manuscript texts, transcribers also encode features like corrections, nomina sacra, Andrew of Caesarea kephalaia, capitals, changes of hand, and different ink colors, embedding these items in the underlying data of the edition. ${ }^{9}$ This editorial approach reflects broader changes in the conceptions of the purpose and functionality of the critical edition brought about by the proliferation of manuscript images. Editions construct the narrative of a work's text, but they also furnish the narrative of a work's material reception when connected to digital manuscript images and editorial metadata. Forms of New Philology are beginning to impinge upon editorial practices, creating a sprawling agenda of further editorial engagement with the New Testament's manuscripts.

It is in this context that a fresh examination of manuscript technology itself and the way that readers process this technology is required. If manuscripts "are a physical manifestation of human communication," 10 then their paratextuality shapes modes of interpretation and reading. As we continue to develop new forms of digital editing and edition making, we should seek ways to represent the paratextual complexity of the tradition, reconnecting the textual and material in digital spaces. ${ }^{11}$ We should also attempt to explore the cognitive functions of paratexts-that is, the way that paratexts direct the mind and influence interpretation-through interdisciplinary engagement, particularly with aesthetics and the cognitive sciences. Editorial choices about what information to encode in digital transcriptions have been constrained, for good reasons, by the pragmatics of producing print critical editions and textual reconstruction. But we are now in a position to begin to imagine new and complementary ways of engaging

Print editions of Acts and the Catholic Epistles have also appeared: Barbara Aland et al., eds., Novum Testamentum Graecum: Editio Critica Maior IV: Die Katholischen Briefe, 2nd ed. (Stuttgart: Deutsche Bibelgesellschaft, 2013); Holger Strutwolf et al., eds., Novum Testamentum Graecum: Editio Critica Maior III: Die Apostelgeschichte (Stuttgart: Deutsche Bibelgesellschaft, 2017).

${ }^{9}$ See Marcus Sigismund, "Die neue Edition der Johannesapokalypse: Stand der Arbeit," in Studien zum Text der Apokalypse II, ed. Marcus Sigismund and Darius Müller, ANTF 50 (Berlin: de Gruyter, 2017), 3-17.

${ }^{10}$ Judith Waring, "Byzantine Book Culture," in A Companion to Byzantium, ed. Liz James, Blackwell Companions to the Ancient World (Oxford: Blackwell, 2010), 275-88, here 275.

${ }^{11}$ Work has begun along these lines for multiple manuscript cultures, including the New Testament. See, e.g., Lied and Maniaci, Bible as Notepad, especially Andrist's “Toward a Definition of Paratexts and Paratextuality," 130-49. For reflection on the materiality of digital images, see also Garrick V. Allen, "Digital Tools for Working with New Testament Manuscripts," Open Theology 5 (2019): 13-28, https://doi.org/10.1515/opth-2019-0002.

This article was published in JBL 140/2 (2021) 409-434, copyright ( 2021 by the Society of Biblical Literature. To purchase copies of this issue or to subscribe to JBL, please contact SBL Customer Service by phone at 866-727-9955 [toll-free in North America] or 404-727-9498, by fax at 404-727-2419, or visit the online SBL Store at www.sbl-site.org. 
manuscripts that reflect the complexities of their production and concerns beyond the purely textual.

To demonstrate that a new editorial agenda focused on the paratextuality of overlooked manuscripts from a new philological perspective is of critical value to biblical studies, I explore the ways in which one gospel book-the hitherto unpublished CBL W 139 (GA 2604; diktyon 13571) ${ }^{12}$-mediates the gospel text through the deployment of paratextual apparatuses that inculcate nonlinear forms of reading. I do this by providing an overview of the manuscript and by working through a narrative thought experiment based on the manuscript's evidence of usage. The manuscript's reading pathways direct users to deploy conflicting reading protocols for traversing the web of traditions that inhabit its physical space, serving not only as a witness to the Greek text of the gospels in the twelfth century, ${ }^{13}$ but also to the ubiquitous traditions that control readerly engagement with this artifact and others like it. The layout, content, and paratexts of this manuscript embolden users to follow embedded conduits of tradition that explain the content of the gospels, their contexts of production, and their literary interrelationships. This examination shows that manuscripts are valuable for a range of critical questions and approaches, and, more specifically, that new editorial approaches are required to capture complexities of each witness to the New Testament's text.

${ }^{12} \mathrm{CBL}$ W 139 has been available in digitized black-and-white microfilm at http://ntvmr .uni-muenster.de/, which now also has the color images first made at http://www.csntm.org/ manuscript/View/GA_2604. I have found no substantial references to this manuscript in any publication. Its entry is blank in J. K. Elliott, A Bibliography of Greek New Testament Manuscripts, 3rd ed., NovTSup 160 (Leiden: Brill, 2015). It is briefly mentioned in M. Aubineau, "Glanes hagiographiques dans les manuscrits grecs de Grande-Bretange et d'Irlande," AnBoll 86 (1968): 323 31 , here 324, but not mentioned in any other published work, even those that explicitly focus on the biblical material of the Chester Beatty, e.g., Kevin J. Cathcart, "The Biblical and Other Early Christian Manuscripts of the Chester Beatty Library," in Back to the Sources: Biblical and Near Eastern Studies in Honour of Dermot Ryan, ed. Kevin J. Cathcart and John F. Healey (Dublin: Glendale, 1989), 129-63.

${ }^{13}$ The text of W 139 is not of significant text-critical interest, which explains why it has never served as a witness in any edition of the New Testament or been published in any context besides its digitization. According to Text und Textwert (accessed through the Manuscript Clusters tool, http://intf.uni-muenster.de/TT_PP/TT_Clusters.html), it agrees with the Majority reading in 96 percent of its test passages. For further analysis of the text of the New Testament in other deluxe gospel books, see Kathleen Maxwell, "The Textual Affiliation of Deluxe Byzantine Gospel Books," in The New Testament in Byzantium, ed. Derek Krueger and Robert S. Nelson, Dumbarton Oaks Byzantine Symposia and Colloquia (Washington, DC: Dumbarton Oaks Research Library and Collection, 2016), 33-85 (she does not reference W 139).

This article was published in JBL 140/2 (2021) 409-434, copyright ( 2021 by the Society of Biblical Literature. To purchase copies of this issue or to subscribe to JBL, please contact SBL Customer Service by phone at 866-727-9955 [toll-free in North America] or 404-727-9498, by fax at 404-727-2419, or visit the online SBL Store at www.sbl-site.org. 


\section{The Manuscript (Dublin, CBL W 139, GA 2604)}

TABLE 1. Contents of CBL W 139

\begin{tabular}{|c|c|}
\hline Folio & Item \\
\hline $1 \mathrm{v}$ & Icon of John Chrysostom (with Paul and Proclus) \\
\hline $2 \mathrm{r}-4 \mathrm{r}$ & Decorated cruciform Letter to Carpianus \\
\hline $4 \mathrm{v}-9 \mathrm{r}$ & Decorated Eusebian canon tables \\
\hline $9 \mathrm{v}-11 \mathrm{r}$ & Matthew Kephalaia Table \\
\hline $11 \mathrm{v}-12 \mathrm{r}$ & 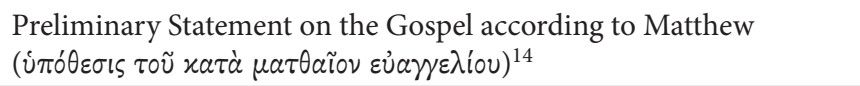 \\
\hline $12 \mathrm{v}$ & Blank \\
\hline $13 r-21 r$ & 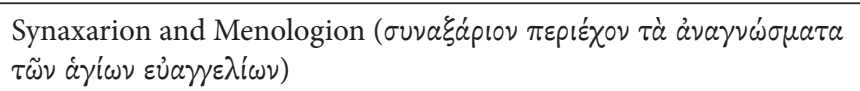 \\
\hline $21 v-22 v$ & 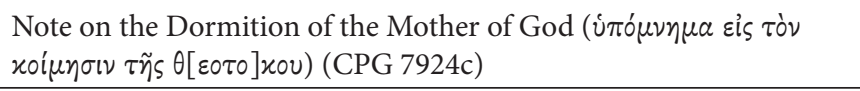 \\
\hline $22 \mathrm{v}$ & Situation specific readings \\
\hline $23 r-24 r$ & 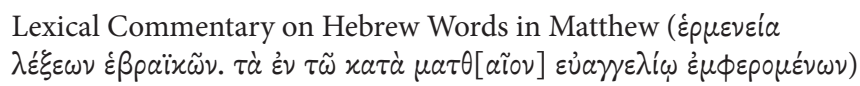 \\
\hline $24 r-25 v$ & 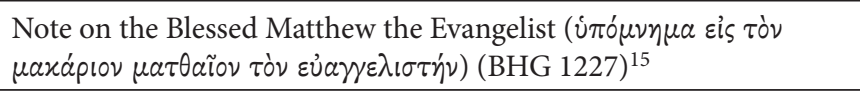 \\
\hline $25 v-28 v$ & 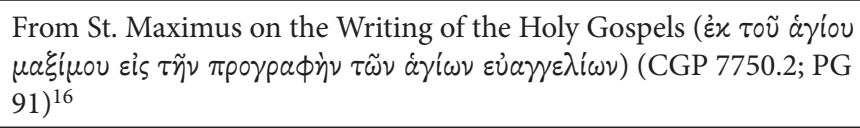 \\
\hline $29 \mathrm{r}$ & Blank \\
\hline $29 \mathrm{v}$ & Icon of Matthew the Evangelist \\
\hline $30 \mathrm{r}-119 \mathrm{v}$ & $\begin{array}{l}\text { Matthew with Catena (Peter of Laodicea, CPG c111, similar to } \\
\text { Reuss Type B) }\end{array}$ \\
\hline $120 \mathrm{r}-121 \mathrm{r}$ & Mark Kephalaia Table (with explanation on Hebrew names) \\
\hline
\end{tabular}

${ }^{14}$ Anonymous, but attributed to Irenaeus in Athos, Iviron 56 (GA 1006). See also Athens, Nat. Bib. 76 (GA 776); and Hermann von Soden, Die Schriften des Neuen Testaments in ihrer ältesten erreichbarren Textgestalt, vol. 1, part 1, Abteilung: Die Textzeugen (Berlin: Duncker, 1902), 314 (hereafter von Soden 1.1).

${ }^{15}$ See abbreviated form of this text in von Soden 1.1:305.

${ }^{16}$ The text is nearly identical to Ambiguum 21.4-12 in Nicholas Constas, ed., On Difficulties in the Church Fathers: The Ambigua, 2 vols., Dumbarton Oaks Medieval Library 28-29 (Cambridge: Harvard University Press, 2014), 1:424-39. 


\begin{tabular}{|c|c|}
\hline Folio & Item \\
\hline $121 \mathrm{v}$ & 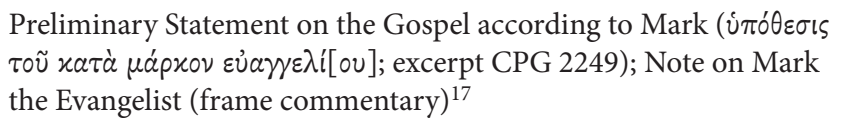 \\
\hline $122 \mathrm{r}$ & Blank \\
\hline $122 \mathrm{v}$ & Icon of Mark the Evangelist \\
\hline $123 r-178 \mathrm{r}$ & Mark with Catena (CPG c125, similar to Reuss Type A) \\
\hline $178 \mathrm{v}-180 \mathrm{r}$ & $\begin{array}{l}\text { Luke Kephalaia Table; and Hebrew names list; ن́ } \pi \text { ó } \mu \nu \eta \mu \alpha \text { (the latter } \\
\text { two as frame commentary) }{ }^{18}\end{array}$ \\
\hline $180 \mathrm{v}$ & 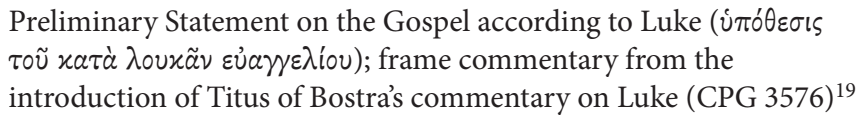 \\
\hline $181 \mathrm{r}$ & Blank \\
\hline $181 \mathrm{v}$ & Icon of Luke \\
\hline $182 \mathrm{r}-277 \mathrm{r}$ & Luke with Catena \\
\hline $277 \mathrm{v}-278 \mathrm{r}$ & 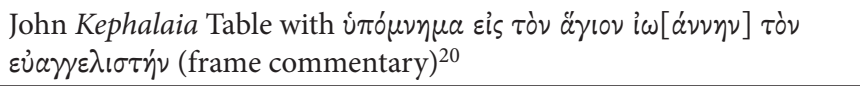 \\
\hline $278 \mathrm{r}$ & Explanation of Hebrew Names in John \\
\hline $278 v$ & Icon of John and Prochorus \\
\hline $279 r-378 v$ & John with Catena (similar to Reuss Type B) \\
\hline
\end{tabular}

CBL W 139 is a maximalist early twelfth-century gospel book in terms of its paratexts and, as such, is a good example for the possibilities of editing in the context of New Philology. ${ }^{21}$ It retains a secondary but medieval binding and what appears to be its original purple fabric over its wood covers. The totality of the contents of the codex are preserved, including its flyleaves. Its folio size is consistent

${ }^{17}$ The $\dot{\tau} \pi \dot{\theta} \theta \varepsilon \sigma ı \varsigma$ can be found in von Soden 1.1:314-15 and is also preserved in Nicetas

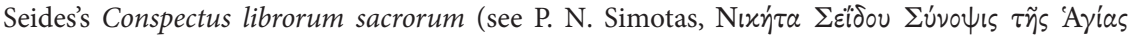
Графи̃s [Thessalonica: Patriarchal Institute for Patristic Studies, 1984], 273). The text of the frame can be found in von Soden 1.1:574, 583.

${ }^{18} \mathrm{An}$ abbreviated form is cataloged in von Soden 1.1:306.

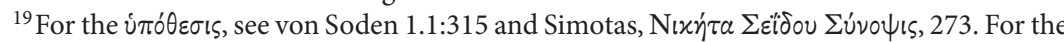
frame, see Joseph Sickenberger, Titus von Bostra: Studien zu dessen Lukashomilien, TUGAL 21 (Leipzig: Hinrichs, 1901), 143.

${ }^{20}$ See von Soden 1.1:306 (abbreviated form).

${ }^{21}$ It is also part of a larger tradition of deluxe Byzantine gospel books. For examples, see, e.g., Axinia Džurova with Paul Canart, Le rayonnement de Byzance: Les manuscrits grec enluminés des Balkans (VIe-XVIIIe siècles); Catalogue d'exposition, XXIIe Congrès internationales détudes byzantines, Sofia, 22-27 août 2011 (Sofia: Galerie Nationale d’Art étranger, 2011). 
with and identical to the size of the covers $(24.8 \times 19.7 \mathrm{~cm}$, with a slightly taller spine). The quality of its production and the extent of its contents are luxurious; its 378 parchment leaves (756 pages) contain the four gospels with catenae (some of which fall into traditional patterns), ${ }^{22}$ icons of the evangelists (and John Chrysostom), and nearly every possible paratextual system available in this period..$^{23}$ These paratexts include tables of contents ( $\varkappa \varepsilon \phi a ́ \lambda \alpha \iota \alpha)$ with titles $(\tau i \tau \lambda \circ \iota)$, Eusebian canon tables, a cruciform Epistle to Carpianus, full lection tables, ${ }^{24}$ epigrams on the evangelists, a preface on the composition of the gospels, a short text on the dormition

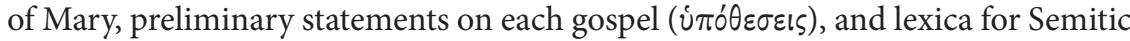

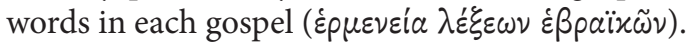

The codex's care of production is witnessed also in its consistency and its long shelf life. Each folio of gospel text retains consistent ruling lines (twenty lines of main text per folio), accompanied by clear script with gilded capitals, kephalaia notations, intertitles, and section/canon numerals in the margins. The script of the marginal catenae is clear, although laden with more ligatures than the scriptural text. ${ }^{25}$ The manuscript was also carefully repaired using an illuminated music score due to water damage, and a later hand inserted additional liturgical notations, suggesting a significant duration of usage. ${ }^{26}$ Even the recycled material used as flyleaves is also highly legible (but bound upside down) and from a tradition (probably coincidentally) related to the gospels - a bicolumnar tenth-century copy of John Chrysostom's Homilies on Matthew 52-54 (CPG 4424). ${ }^{27}$

The design of the manuscript prescribes a hierarchy within the arrangement of the codex and each mise-en-page. ${ }^{28}$ The text of the gospels is the focal point of

\footnotetext{
${ }^{22}$ On catenae in Byzantine literature, see Herbert Hunger, Schreiben und Lesen in Byzanz: Die byzantinische Buchkultur, Beck's archäologische Bibliothek (Munich: Beck, 1989), 29-30; and on the New Testament specifically, see H. A. G. Houghton, ed., Commentaries, Catenae and Biblical Tradition, TS 13 (Piscataway, NJ: Gorgias, 2016); and William Lamb, "Conservation and Conversation: New Testament Catenae in Byzantium," in Krueger and Nelson, New Testament in Byzantium, 277-99.

${ }^{23}$ For an overview of these systems, see W. H. P. Hatch, Facsimiles and Descriptions of Minuscule Manuscripts of the New Testament (Cambridge: Harvard University Press, 1951), 22-39.

${ }^{24}$ On the structure of these traditions, see Bruce M. Metzger, "Greek Lectionaries and a Critical Edition of the Greek New Testament," in Die alten Übersetzungen des Neuen Testaments: Die Kirchenväterzitate und Lektionare; Der gegenwärtige Stand ihrer Erforschung und ihre Bedeutung für die griechische Textgeschichte, ed. Kurt Aland, ANTF 5 (Berlin: de Gruyter, 1972), 479-97, esp. 480-84.

${ }^{25}$ There are also some corrections in the catena texts by a later hand using a darker ink, e.g., $38 \mathrm{v}$ line 1 of the $\beta$ catena, indicating editorial oversight.

${ }^{26}$ Repairs of damage are visible on fols. $154-57,160,164-65,167,171-72,175-78,183,188$, $223-44,246-50,252,256,258-61,263-69,271-72,274,296-98,308-9,329,332-33,338-39$, $343,346-47,350-51,353,355,362-63,365-67,369-70$.

${ }^{27} \mathrm{~A}$ point missed in the CSNTM catalogue entry (http://images.csntm.org/Manuscripts/ GA_2604/GA\%202604\%20(CBL\%20W\%20139).pdf).

${ }^{28}$ This phenomenon is not unique to the New Testament but characterizes medieval textual
} 
the codex, standing at the physical center of each folio, and other parts of the codex are graphically subordinate to the gospel texts. The gospels in W 139 are mediated by a thick layer of tradition that functions as a locus of reception-historical evidence for how the gospels were conceived and organized; the manuscript mediates and contextualizes the text through the lens of tradition.

The mediation of the gospel text in W 139 makes it a complex arbiter of knowledge about the gospels and their interrelationships insofar as it stands as an inanimate object between its producers and its users. The presence of prefatory and indexical paratexts before each gospel is important in this regard, embedding traditions of segmentation and lexical interpretation, but they are not the only way that these traditions impinge on the formation of the manuscript's networks. With the exception of the Epistle to Carpianus, the icons, and the preliminary notes on each gospel and its evangelist, each of the manuscript's paratextual systems is also integrated into the margins of the gospel text in a series of interlocking cross-references that direct readers to the various tables at the outset of the codex and other parallel texts. ${ }^{29}$ And each system has its own agenda, many of which are well known, like the Eusebian canon tables and corresponding marginalia, a series of numerated pericopae that map onto ten tables that enable readers to traverse the interrelationships of the fourfold gospel. ${ }^{30}$ Significant research has been carried out on this apparatus in recent years, ${ }^{31}$ but less attention has been given to the older kephalaia,

cultures more broadly. See Jaqueline Cerquiglini-Toulet, "Conceiving the Text in the Middle Ages," in Rethinking the New Medievalism, ed. R. Howard Bloch et al. (Baltimore: Johns Hopkins University Press, 2014), 150-61.

${ }^{29}$ See Gregory Peter Fewster, "Finding Your Place: Developing Cross-Reference Systems in Late Antique Biblical Codices," in The Future of New Testament Textual Scholarship: From H. C. Hoskier to the Editio Critica Maior and Beyond, ed. Garrick V. Allen, WUNT 417 (Tübingen: Mohr Siebeck, 2019), 153-77.

${ }^{30}$ The Eusebian apparatus comprises three features, which are not always present together in particular manuscripts: (1) the Epistle to Carpianus, (2) the marginal numerals denoting the pericope number and its canon table, and (3) the ten tables themselves, showing the relationship of a pericope to the larger gospel tradition.

${ }^{31}$ See, e.g., Jeremiah Coogan, "Mapping the Fourfold Gospel: Textual Geography in the Eusebian Apparatus," JECS 25 (2017): 337-57; Francis Watson, The Fourfold Gospel: A Theological Reading of the New Testament Portraits of Jesus (Grand Rapids: Baker Academic, 2016), 103-44; Matthew Crawford, "Ammonius of Alexandria, Eusebius of Caesarea and the Origins of Gospels Scholarship," NTS 61 (2015): 1-29; Martin Wallraff, Kodex und Kanon: Das Buch im frühen Christentum, Hans-Lietzmann-Vorlesungen 12 (Berlin: de Gruyter, 2013), 29-37; Thomas O'Loughlin, "Harmonizing the Truth: Eusebius and the Problem of the Four Gospels", Traditio 65 (2010): 1-29; and previously, Carl Nordenfalk, Die spätantiken Kanontafeln: Kunstgeschichtliche Studien über die eusebianische Evangelien-Konkordanz in den vier ersten Jarhunderten ihrer Geschichte, 2 vols., Die Bücherornamentik der Spätantike 1 (Göteborg: Oscar Isacsons, 1938). Wallraff in particular draws attention to Eusebius's other tables for world history and the Psalter, arguing that canon is closely related to the formation of material objects that organize the knowledge they transmit

This article was published in JBL 140/2 (2021) 409-434, copyright ( 2021 by the Society of Biblical Literature. To purchase copies of this issue or to subscribe to JBL, please contact SBL Customer Service by phone at 866-727-9955 [toll-free in North America] or 404-727-9498, by fax at 404-727-2419, or visit the online SBL Store at www.sbl-site.org. 
the lists of Hebrew lexemes that appear in the gospels, and the liturgical notations. ${ }^{32}$ Marginal notes directing attention to the short text "Note on the Dormition of the Theotokos" even occur where Mary appears in the narrative (e.g., 184r: $v \pi 0 \tau \tilde{\eta} s$ $\theta[\varepsilon \circ \tau 0]$ xov, Luke 1:26), creating a broader network of Marian traditions. Additionally, the catenae in the margins of each page retain their own cross-references internal to each folio.

Taking stock of the contents and design of a manuscript are key to understanding the ways that its paratextuality facilitates interpretations of its texts. But straightforward description is not sufficient to grasp the significance of these items and their interrelationships for processes of reading. Another way to analyze the complexity of W 139's cross-referencing systems is through a critical thought experiment in the form of a creative narrative fiction. Narrative thought experiments, commonplace in philosophy and the sciences, are imaginative exercises that "tease out the implications of theories or hypotheses to test their tenability." ${ }^{33}$ This kind of storytelling allows readers to better understand multidimensional processes, like the reception-historical possibilities of a deluxe twelfth-century gospel manuscript. ${ }^{34}$

By crafting an imaginary story around W 139, we can better understand the ways its systems function, raise new questions for further exploration, and begin to see the relevance of manuscript features for larger critical concerns central to biblical studies. The story below constitutes critical research because it demonstrates how manuscripts influence the interpretations of the texts they transmit,

("The Canon Tables of the Psalms: An Unknown Work of Eusebius of Caesarea," DOP 67 [2013]: $1-14)$.

${ }^{32}$ On the kephalaia, see W. Andrew Smith, A Study of the Gospels in Codex Alexandrinus: Codicology, Paleography, and Scribal Hands, NTTSD 48 (Leiden: Brill, 2014), 156-78; Greg Goswell, "Early Readers of the Gospels: The Kephalaia and Titloi of Codex Alexandrinus," JGRChJ 6 (2009): 134-74; Harvey McArthur, "The Earliest Divisions of the Gospels," in SE III.2, ed. F. L. Cross (Berlin: Akademie, 1964), 266-72.

${ }^{33}$ Catherine Z. Elgin, "Art in the Advancement of Understanding," American Philosophical Quarterly 39 (2002): 1-12, here 9. See also Christoph Baumberger, "Art and Understanding: In Defence of Aesthetic Cognitivism," in Bilder sehen: Perspektiven der Bildwissenschaft, ed. Mark Greenlee et al., Regensburger Studien zur Kunstgeschichte 10 (Regensburg: Schnell \& Steiner, 2013), 41-67: "Idealizations are fictions designed to afford epistemic access to matters of fact that are otherwise difficult or impossible to discern.... They enable us to explore these features and their causes and consequences by disregarding complications that overshadow them in real cases" (47). In another article Elgin points out that, although thought experiments are not actual, they are bound by self-constraints that restrict the imaginative process ("Fiction as Thought Experiment," Perspectives of Science 22 [2014]: 221-41, here 226-27). The constraints in this case are based on the paratextuality of the manuscript itself.

${ }^{34}$ See John Gibson, “Cognitivism and the Arts," Philosophy Compass 3 (2008): 573-89, here $580-81$.

This article was published in JBL 140/2 (2021) 409-434, copyright ( 2021 by the Society of Biblical Literature. To purchase copies of this issue or to subscribe to JBL, please contact SBL Customer Service by phone at 866-727-9955 [toll-free in North America] or 404-727-9498, by fax at 404-727-2419, or visit the online SBL Store at www.sbl-site.org. 
imagines a possible context of usage, and plays with the idea of how motivations for reading and familiarity with paratextual traditions impinge on interpretation. The story brings to the fore the web of possibilities embedded in the paratextuality of W 139, demonstrating the importance of further editorial and interdisciplinary engagement with manuscripts and their paratextuality and moving beyond (at least for the moment) text-critical questions as the primary driving force behind reading manuscripts in the first place. Thought experiments imaginatively investigate what would happen under certain conditions, and this one explores how a consciencestricken lector called Peter the Shoemaker might have navigated W 139's overlapping cross-referencing systems-the kephalaia lists, Eusebian apparatus, lection lists, and catenae-by focusing in the first instance on a single folio and its possible reading pathways (38v, fig. 1). ${ }^{35}$ This thought experiment is not an example of New Philology as such, but its composition is undergirded by a sensibility that takes seriously the paratextual choices of the producers of this manuscript and the effects of their choices on a reader for whom this manuscript was perhaps the manifestation of the gospels in physical form.

\section{Peter the Shoemaker: A Thought Experiment}

You are a respected cobbler who is also a lector in a neighborhood church in Constantinople around the year 1430. Your friends and neighbors know you as Peter the Shoemaker. And you want to reread the beatitudes in the Sermon on the Mount, in part because you are eager to report your piety to your wife, Anastazia, in light of some recent relational discord brought about by your gambling losses. You feel some measure of guilt about your recent choices and, believing that lectors are judged more harshly in the afterlife, would prefer not to be tormented eternally by a winged beast with three flaming heads (Apoc. Vir. 19) ${ }^{36}$ Knowing that the Sermon on the Mount occurs early on in Matthew's narrative, you stop by the church and open up your community's aged but fine copy of the gospels and turn to the start of the kephalaia table for Matthew near the beginning of the manuscript. On that page (9v), you skim down and find $\varepsilon$ : $\pi \varepsilon p i \tau \tilde{\omega} \nu \mu a x a \rho ı \mu \tilde{\omega} \nu$ (" 5 : Regarding the Beatitudes") (fig. 2).

\footnotetext{
${ }^{35}$ All images of CBL W 139 @ The Trustees of the Chester Beatty Library, Dublin. CC BY-NC 4.0. Images of the entire codex may be found at https://viewer.cbl.ie/viewer/image/W_139/1/.

${ }^{36}$ English translation by Stephen J. Shoemaker, "The Apocalypse of the Virgin: A New Translation and Introduction," in New Testament Apocrypha: More Noncanonical Scriptures, ed. Tony Burke and Brent Landau (Grand Rapids: Eerdmans, 2016), 488-505, here 505.
} 


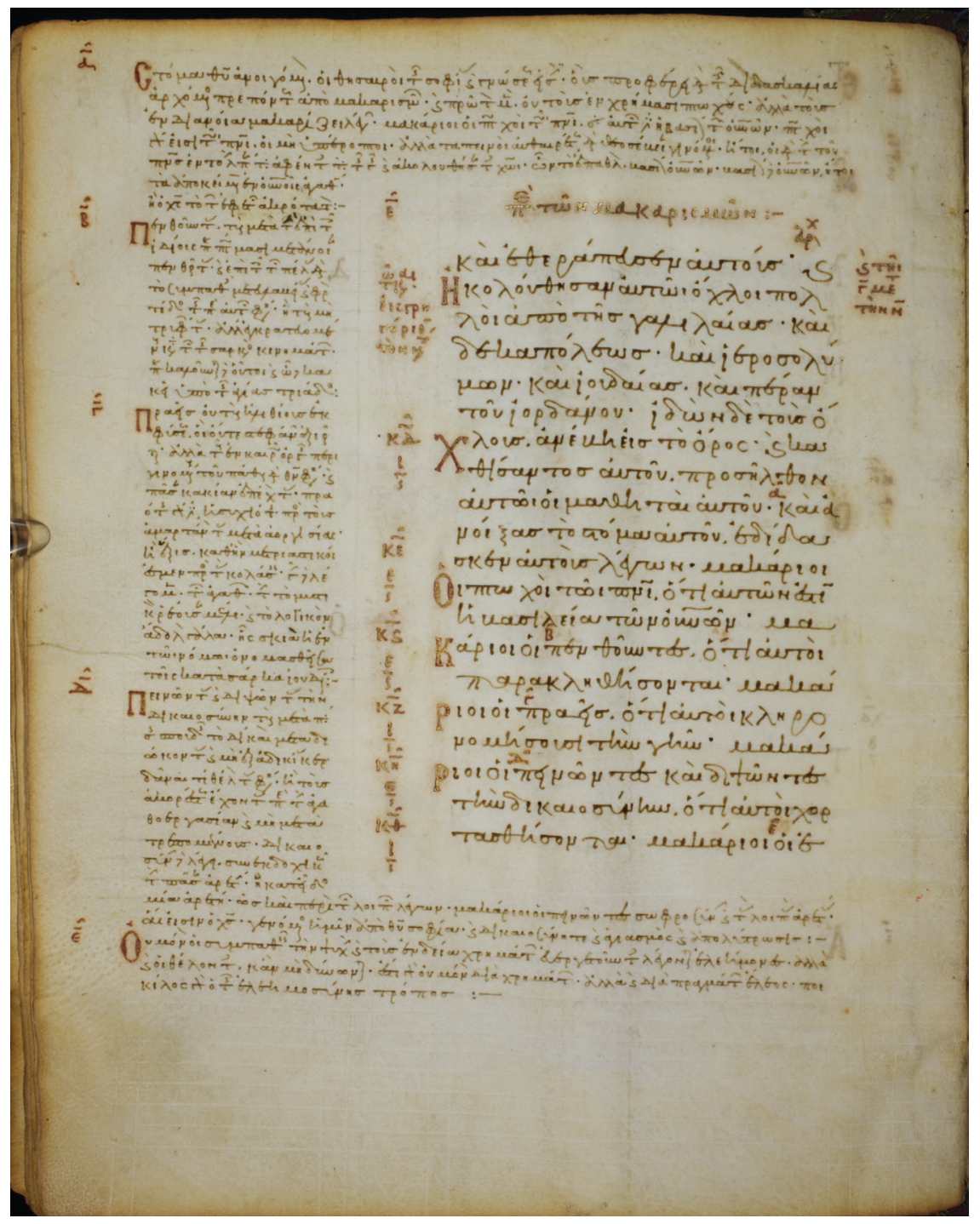

Figure 1. CBL W 139, 38v 


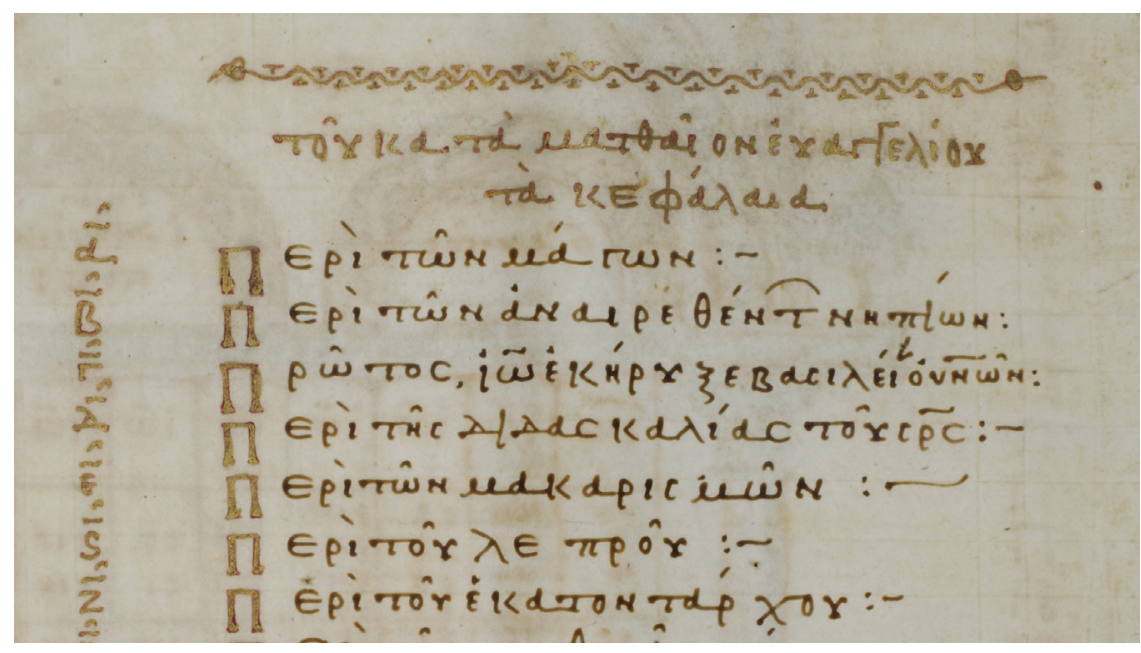

Figure 2. Detail from CBL W 139, 9v

This information is partially helpful. The kephalaia list has sixty-eight chapters for Matthew, so the chapter on the beatitudes will be near the beginning of the text. But you do not know exactly where: there is no indication of the text's location in the larger context of the codex sitting on a table in front of you. So you start to flip pages, turning quickly past prologues, the lection list, and the list of Hebrew words until you arrive at a blank folio (29r) followed by an icon (29v) where Matthew's Gospel begins (fig. 3). 


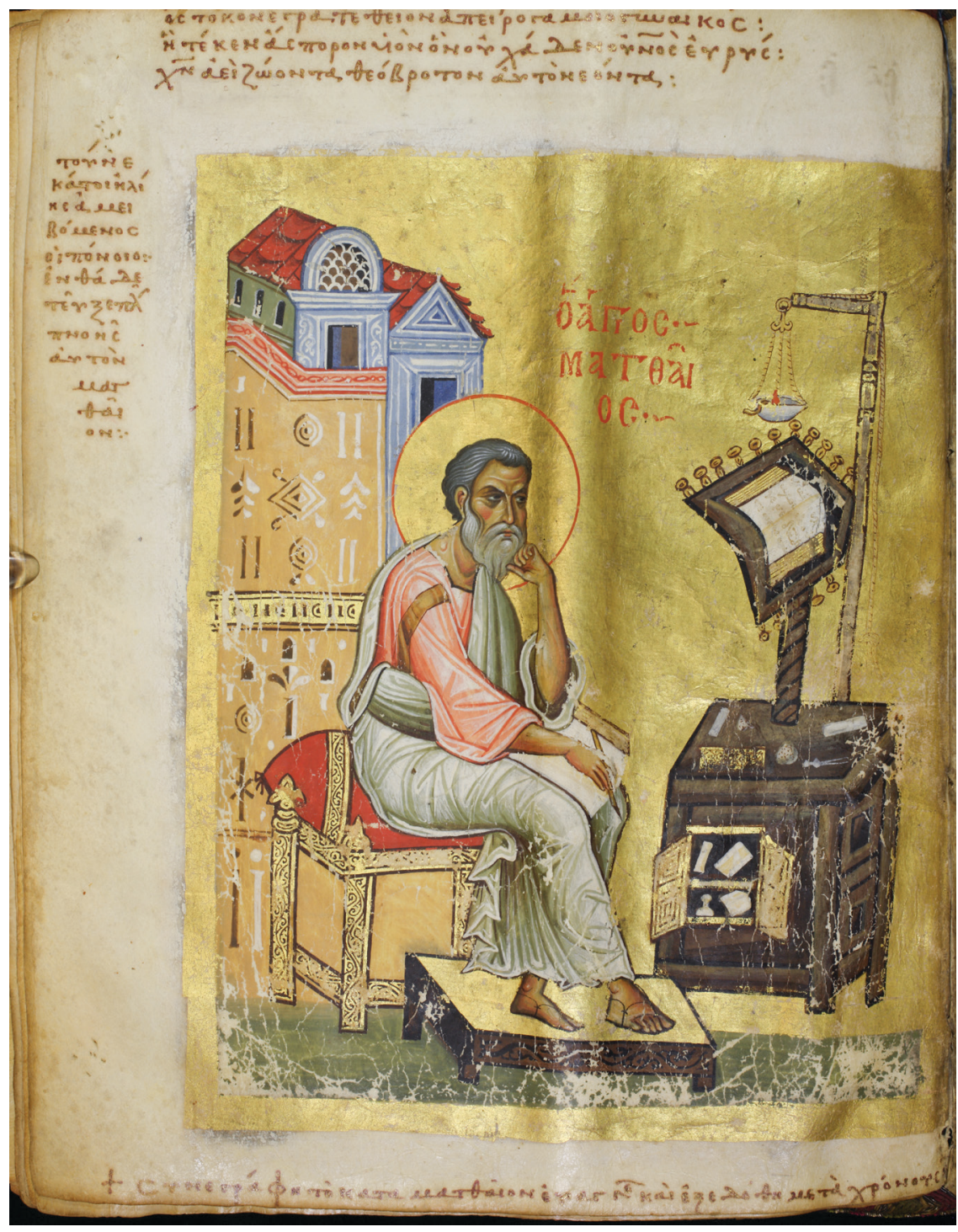

Figure 3. CBL W 139, 29v

You keep flipping, looking for any indication that you have reached your desired location, until, eighteen pages later, you see it: the corresponding kephalaia title located between a commentary extract in the upper margin and the gospel text in gilded script, $\varepsilon: \pi \varepsilon(\rho i) \tau \tilde{\omega} \nu \mu a x a \rho \sigma \mu \tilde{\omega} \nu$ (fig. 4). 


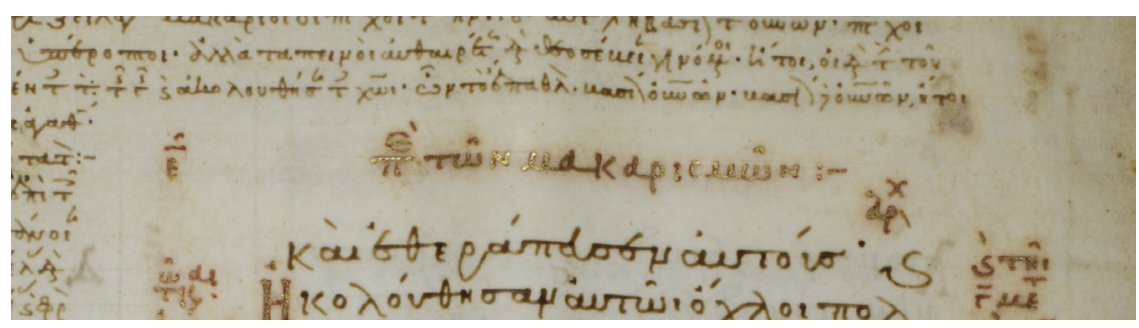

FIgURE 4. Detail from CBL W 139, 38v

The next item that you notice is something familiar to you as lector: lection data, information on when this segment of text is to be read liturgically. Before reading the text on the page itself (Matt 4:24b-5:7a), you want to see when you will next read it aloud. While your initial impetus for reading is a sense of guilt and desire to reconcile with your partner, you also want to practice your elocution in advance of public performance before the congregation. Three marginal items assist in this task. They sit just below the kephalaia title and coalesce around the xal ligature at the end of the first line, corresponding to Matt 4:25 (fig. 5).

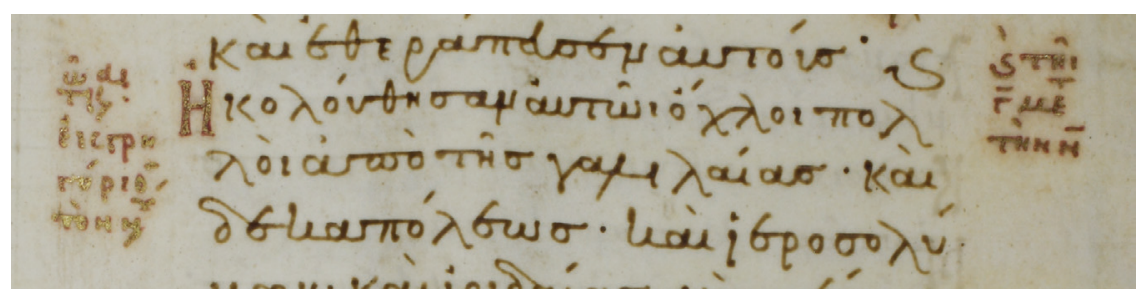

FIGURE 5. Detail from CBL W 139, 38v

Immediately above the xaı ligature and the end of the first line $\alpha^{\chi} \rho^{\chi}$ appears, an abbreviation for 'a $\rho \times \eta$ ' ("beginning"), indicating that xal inaugurates a segment of publicly recited text. Looking over at the facing page (39r), you see a corresponding $\tau^{\varepsilon \lambda}$ ( $\tau \dot{\varepsilon} \lambda \circ \varsigma_{\text {, }}$ "end") on line 14, corresponding to Matt 5:12a, and another in a different red ink in the lower right margin, corresponding to the end of Matt 5:13. You have delineated the lection, but you do not yet know when you will perform it again. Just below and to the right of the ápx' abbreviation you spot a short threeline note: $x a \iota \tau \tilde{\eta} \iota \gamma \mu \varepsilon \tau \alpha \tau \dot{\eta} \nu \eta$, literally "on the third after the eighth." The gamma is an abbreviation for $\tau p$ í $\tau$ ("Tuesday"); you will next read this text on Tuesday of the eighth week of a particular cycle, and, because Matthew is predominantly read in the sixteen weeks from Pentecost to Holy Cross day, you start by turning back to the synaxarion readings of the Pentecost cycle. ${ }^{37}$ Eventually you find the very

${ }^{37}$ On the structure of the Byzantine lection calendar, see Irmgard M. De Vries, "The Epistles, Gospels and Tones of the Byzantine Liturgical Year," ECQ 2/6 (1953): 1-37. On lectionaries 
last week (the week of Pentecost) for the cycle from Easter where readings from John give way to Matthew (14r), locating the following line of the list which has four columns (fig. 6).

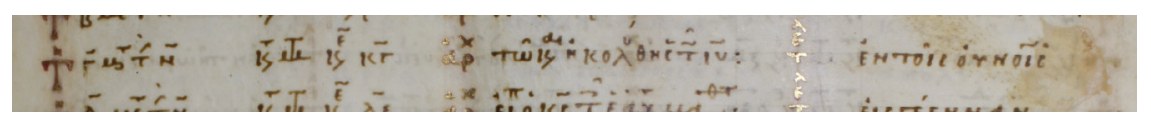

Figure 6. Detail from CBL W 139, 14r

In the left column, you find an even more abbreviated form of the text in the margin that initially sent you to this page ( $\tau \tilde{\eta} \iota \gamma \mu \varepsilon \tau \alpha \tau \dot{\eta} \nu \eta)$. The second column, also abbreviated, reads $x a \tau \alpha \mu(\alpha) \tau(\theta a i o v) x \varepsilon(\phi a \lambda a เ o v) x \gamma$ ("according to Matthew, chapter 23"), a chapter number that does not correspond to the kephalaion entitled "5: Regarding the beatitudes" that initiated your path to the sermon. You quickly

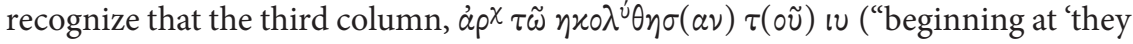
followed Jesus"') designates the starting point of the reading. The final column shows where the reading should end, again signaled by the abbreviation $\tau^{\varepsilon \lambda}$. The

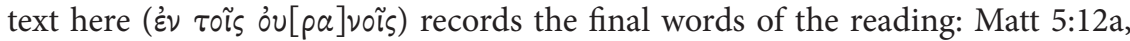
"rejoice and be glad because your reward is great in heaven."

But flipping back to the page of Matthew that you have been holding with your finger, you see another note to the left margin of the main text, parallel to the last marginal note you made short detective work of (fig. 7).

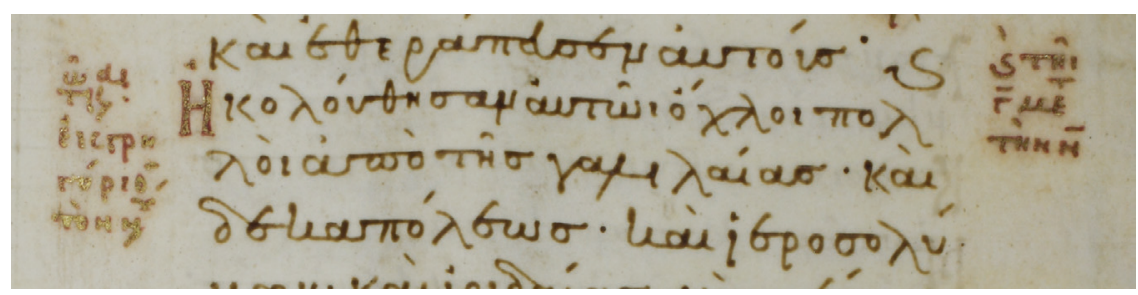

Figure 7. Detail from CBL W 139, 38v

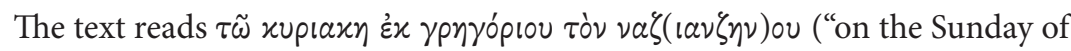
Gregory of Nazianzus"). You know that the feast day for Gregory, the fourthcentury archbishop of Constantinople, is in late January, so you go looking back in the menologion section for readings on special immovable feast days. Eventually (on 20v) you find this at the top of the page, the first line of which is relevant for your search (fig. 8).

generally, see David M. Petras, “The Gospel Lectionary of the Byzantine Church," SVTQ 41 (1997): 113-40; Jacque Noret, “Méneloges, synaxaires, ménés: Essai de clarification d’une terminologie," AnBoll 86 (1968): 21-24. 


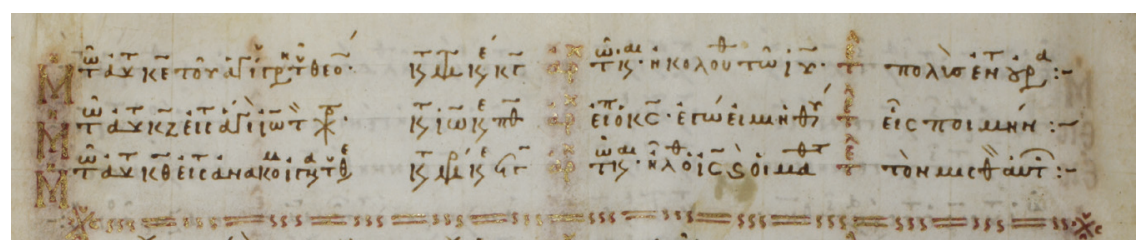

FIGURE 8. Detail from CBL W 139, 20v

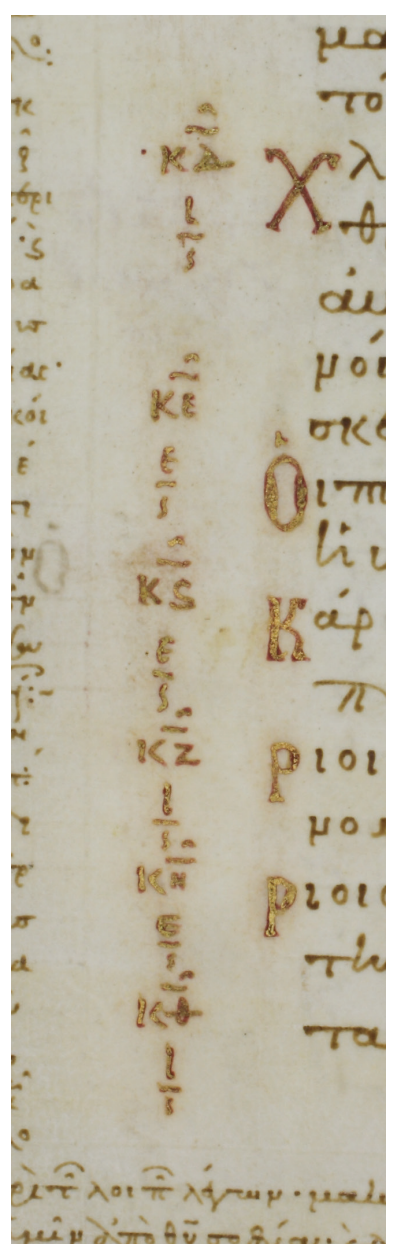

FIGURE 9. Detail from CBL W 139, 38v
The structure is identical to the reading you located at the end of the Easter cycle of readings (14r). The second column gives the location of the reading (Matthew chapter 23), the third gives the first four words of the readings, and the fourth gives the final three words. The first column, which connects to the marginal comment in left margin of the main text reads: $\mathrm{M}^{\nu} \tau^{\tilde{\omega}} \dot{\alpha} u^{\tau} \chi \varepsilon \tau 0 \tilde{u} a \gamma i^{\nu} \gamma \rho^{\eta} \tau^{\tilde{v}} \theta \varepsilon \circ$ (or less

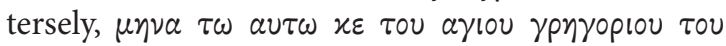
$\theta \varepsilon 0 \lambda$ oyou, "on the 25 th of the same month [iavvovapíw, see line 13 on 20r] regarding Saint Gregory the Theologian"). Satisfied that you will not have to perform the text for some time, you return to the $38 \mathrm{v}$, where you finally begin to read the text. The only thing that does not line up is the fact that you are reading chapter $5(\varepsilon)$ according to Matthew's sixty-eight chapters. Although the lections seem to indicate that $38 \mathrm{v}$ begins on chapter $23(\kappa \gamma)$, you know that the synaxarion is aligned with the Eusebian sections, not the kephalaia system.

As you read the main Gospel text and reach the second gilded initial letter-a large chi that protrudes into the negative space between scholia and textyou see another segmenting device that corresponds to the chapter numbers mentioned in the synaxarion. Immediately left of the $c h i$, you read an ornate $x \delta / l$ $\left(24_{10}\right)$. If the synaxarion thought you were on chapter 23 , you have now reached 24. Below this on the page, you also find other chapter numbers in quick succession, each of which has the numeral five or ten immediately beneath them: $x \varepsilon / \varepsilon\left(25_{5}\right), x \varsigma / \varepsilon\left(26_{5}\right), x \zeta / 1$ $\left(27_{10}\right), x \eta / \varepsilon\left(28_{5}\right)$, and $x \theta / \iota$ ( $\left.29_{10}\right)$ (fig. 9). 
You know that these sigla are part of the Eusebian system that embeds crossreferences in gospel pericopae. The first number corresponds to a linear numeration of each pericope of Matthew, segmented by Eusebius and influenced by his Vorgänger Ammonius mentioned in the Epistle to Carpianus $(2 \mathrm{r}-4 \mathrm{r}){ }^{38}$ There are 355 chapters or sections in Eusebius's system in Matthew, as opposed to the 68 kephalaia enumerated in the chapter lists at the start of the gospel $(9 \mathrm{v}-11 \mathrm{r})$. The Greek numeral under the chapter number connects the pericope to one of ten tables (4v-9r), where parallel passages in Mark, Luke, and John can be identified where parallels exist. The number of the table determines the type of relationship the pericope has to other similar texts in other gospels.

The six Eusebian notations on this folio fall into one of two canons: 10 (indicating the text's uniqueness among the other gospels), and 5 (Matthew // Luke), which is not surprising given the close relationships between the Matthean Sermon on the Mount and the Lukan Sermon on the Plain. Glancing at the canon number of these notations, you know that the notice that Jesus and his disciples ascended a mountain (Matt 5:1), the beatitude of the meek (5:5), and the beatitude of the merciful (5:7) are Matthean alone, since they fall into canon 10. But you want to follow up on $25_{5}$ (Matt 5:2-3) because you are interested to know more about the "poor in spirit"; perhaps you might still learn how to gain the kingdom of heaven, even if you have fettered most of your income. So you turn to canon 5 at the beginning of the codex and look for number $x \varepsilon(25)$ in the Matthew column $(7 \mathrm{v})$. On the fifth line of the first column of this ornate table you find it, paired with $\mu \varsigma$ (46) in the Luke column (fig. 10).

Searching for the Lukan parallel, you then turn dozens of folios to Luke, noticing the beginning of the text with the icon on 181v. From there you flip page by page, tracking the linear growth of Eusebian section numbers until you come to $\mu \varsigma$ on $204 \mathrm{r}$ (Luke 6:20). The texts are not entirely identical, but the resemblance is obvious.

\begin{tabular}{|c|c|}
\hline Matt $5: 2-3, x \varepsilon(38 \mathrm{v})^{39}$ & Luke $6: 20, \mu \varsigma(204 r)$ \\
\hline 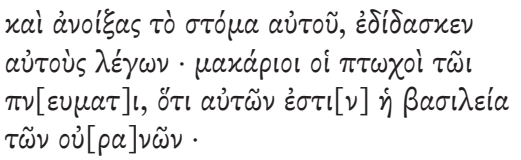 & 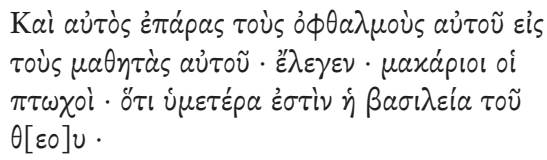 \\
\hline $\begin{array}{l}\text { And opening his mouth, he taught them } \\
\text { saying: Blessed are the poor in spirit, be- } \\
\text { cause theirs is the kingdom of heaven. }\end{array}$ & $\begin{array}{l}\text { And raising his eyes to his disciples, he } \\
\text { said: Blessed are the poor, because yours is } \\
\text { the kingdom of God. }\end{array}$ \\
\hline
\end{tabular}

${ }^{38}$ On the relationship between the work of Ammonius and Eusebius, see Matthew R. Crawford, The Eusebian Canon Tables: Ordering Textual Knowledge in Late Antiquity, OECS (Oxford: Oxford University Press, 2019), 56-95.

${ }^{39}$ The tables are transcriptions of the texts as they stand in the manuscript. 


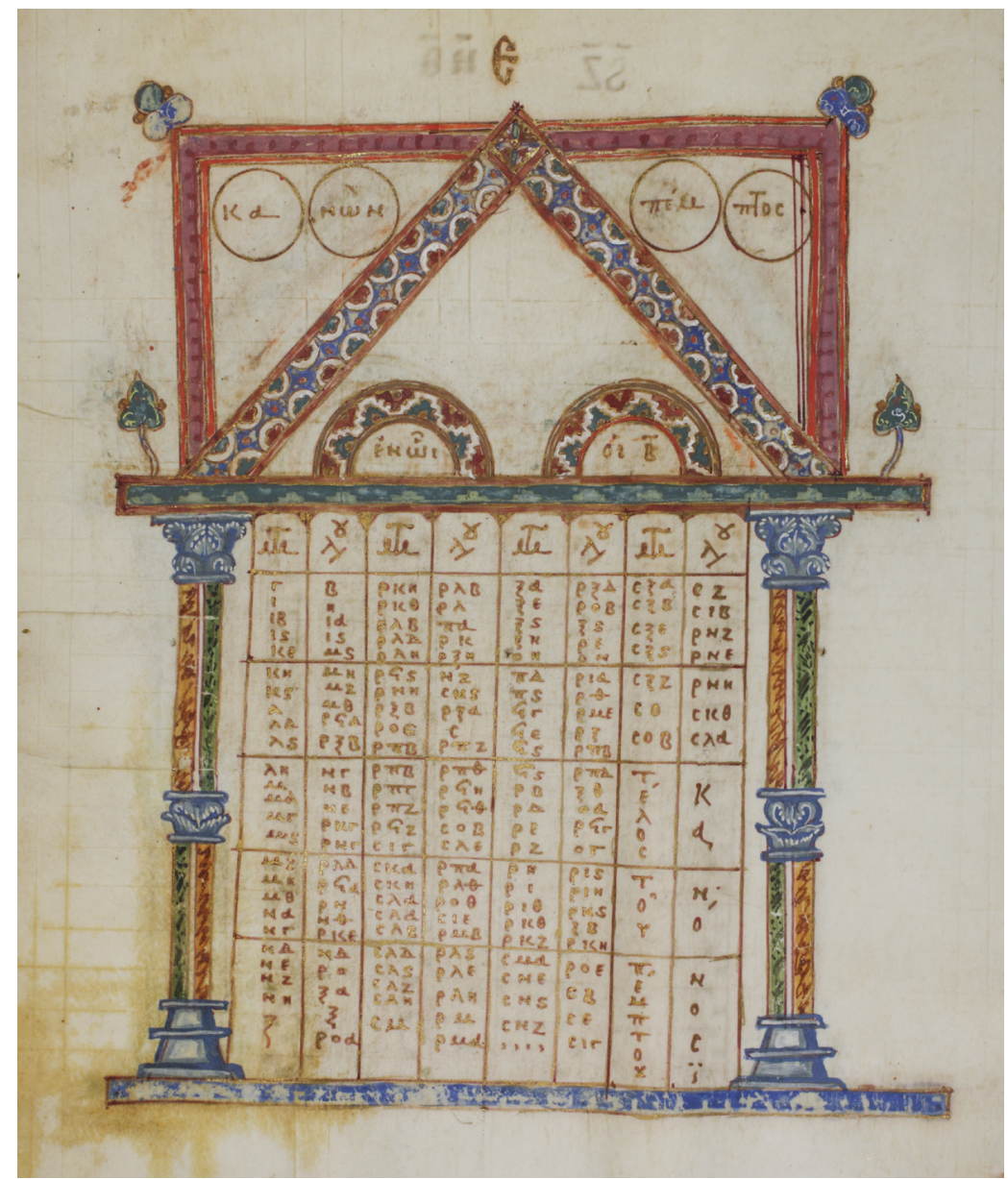

FIGURE 10a. CBL W 139, 7v

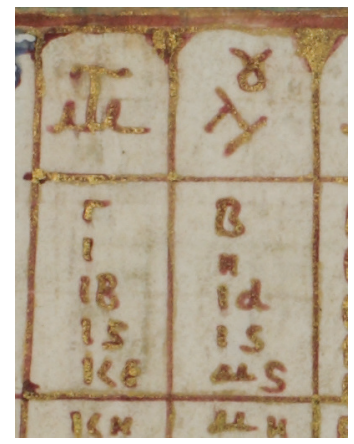

FIGURE 1ob. Detail from CBL W 139, 7v 
Both texts have a narrative introduction that focuses on one of Jesus's facial features, a macarism about the poor or poor in spirit, and a subordinate clause that asserts an inheritance in a kingdom, be it "of God" or the characteristically Matthean "of heaven." The Lukan passage reinforces the idea that the kingdom of God belongs to those who are poor in terms of material wealth (especially when read alongside the first woe in Luke 6:24); Luke's version is, on the surface, more germane to your situation than Matthew's metaphorical "poor in spirit." You can supplement what you have gleaned from the Sermon on the Mount with Luke's version when you return to speak with your partner about faith and finances-perhaps it is better to be poor after all. You flip back to $38 \mathrm{v}$.

There you come back to the beginning of Matt 5:2 to continue reading the passage, trying to find more information on what it means to be "poor in spirit." When you reach $x a i$ a $\alpha{ }^{\prime} i \xi a s$, you notice another cross-referencing symbol in the form of an interlinear alpha directly over the kappa of xal (fig. 11).

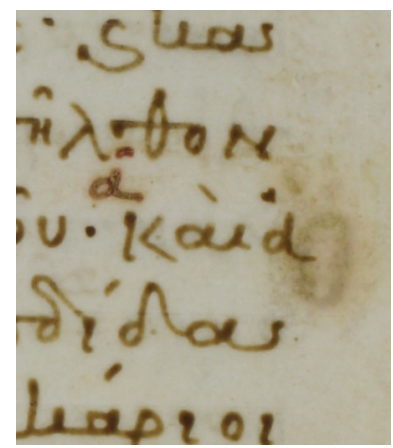

FIgURE 11. Detail from CBL W 139, 38v

Zooming out to the entire folio, you turn your attention to a series of enumerated $(\alpha-\varepsilon)$ scholia that frame the upper, lower, and outer margin of the scriptural text. You find the text connected to the interlinear alpha in the upper margin, just above the kephalaion title that brought you to the folio in the first place (fig. 12).

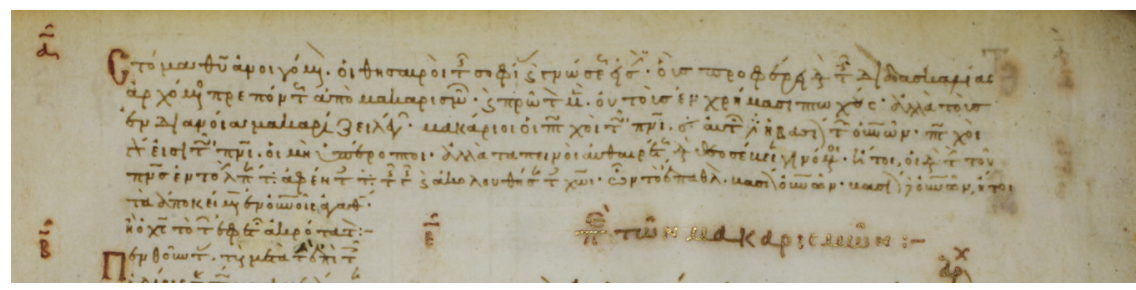

FIgURE 12. Detail from CBL W 139, 38v

This article was published in JBL 140/2 (2021) 409-434, copyright $@ 2021$ by the Society of Biblical Literature. To purchase copies of this issue or to subscribe to JBL, please contact SBL Customer Service by phone at 866-727-9955 [toll-free in North America] or 404-727-9498, by fax at 404-727-2419, or visit the online SBL Store at www.sbl-site.org. 
Although the comments are anonymous, their presence on the page surrounding the gospel text gives them the imprimatur of traditional authority. ${ }^{40} \mathrm{In}$ case the text to be commented on is not yet clear from the corresponding alpha siglum, the commentary begins with a Stichwort, a brief repetition of the text in question: $\sigma \tau \delta^{\prime} \mu \alpha$. You turn to the comment and read that the mouth of God $\left(\sigma \tau \sigma^{\prime} \mu \alpha\right)$ is the storehouse of wisdom and knowledge, which Jesus presents through teaching that begins with the macarisms. ${ }^{41}$ Special attention should be paid to this text because the narrator of Matthew tells us that it comes directly from Jesus's mouth $(\sigma \tau o ́ \mu \alpha)$. The blessing of Jesus, you read, is for the poor in spirit, not those who are

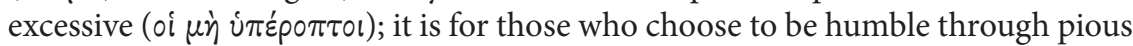

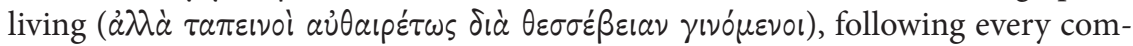

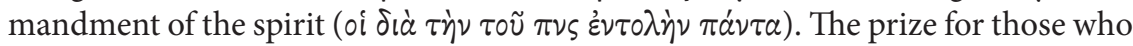
follow Christ in this way is the kingdom of heaven ( $\dot{a} x 0 \lambda \circ v \theta \dot{\eta} \sigma \alpha \nu \tau \omega \chi[\rho / \sigma \tau] \omega \iota \cdot \tilde{\omega} \nu$

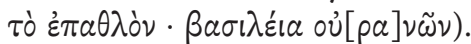

The commentary reifies the moral import of the text: it comes directly from Jesus's mouth and teaches that being poor in spirit means humbling oneself by following the laws of the spirit, making one eligible for the main prize-entrance in the kingdom of heaven. The phrase "laws of the spirit" reminds you of the famous "fruits of the spirit" enumerated in Gal 5:22-23: love, joy, peace, patience, kindness, generosity, faithfulness, gentleness, and self-control. The final item in this list-selfcontrol-alters your perspective on your stressed marital relationship and finances; you have been excessive, and your actions certainly cannot be described as "poor in spirit," even if they did make you financially poorer. As Gal 5:24 reminds you, "Those who belong to Christ Jesus have crucified the flesh with its passions and

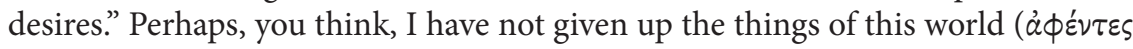
$\tau \dot{\alpha} \tau \tilde{\eta} \varsigma \gamma \tilde{\eta} \varsigma)$ as the commentary recommends. Before setting the book down, and chastened by the reading experience, you randomly turn to a page (310v) and write a small prayer in the lower margin as a contrite act of devotion and reflection of your hope for your family-that God will remember you when it comes time to decide who enters his kingdom (fig. 13).

${ }^{40}$ CPG c111, similar to Reuss Type B. C. F. Georg Heinrici attributed this class of catena manuscript to Peter of Laodicea (seventh-eight century) in Des Petrus von Laodicea Erklärung des Matthäusevangeliums, Beiträge zur Geschichte und Erklärung des Neuen Testamentes 5 (Leipzig: Dürr, 1908), an attribution criticized by Max Rauer, who analyzed Peter traditions in Luke (Der dem Petrus von Laodicea zugeschriebene Lukaskommentar, NTAbh 8.2 [Münster: Aschendorff, 1920], 74-75). The commentary is attributed to Peter of Laodicea in Vat. gr. 1445 (and its copy C. Vat. 1090, along with Vat. gr. 757), but Joseph Reuss, following Rauer, argues for its anonymity (Matthäus-, Markus- und Johannes-Katenen nach den handschriftlichen Quellen, NTAbh 18.4-5 [Münster: Aschendorff, 1941], 3-4).

41 "Mouth of God being opened: it is the storehouses of wisdom and knowledge, which he

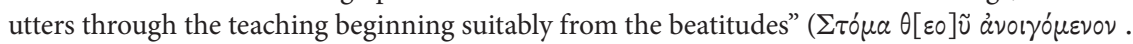

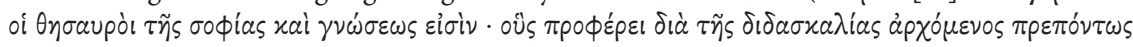
àtò $\mu a x a p เ \sigma \mu \tilde{\omega} \nu)$. 


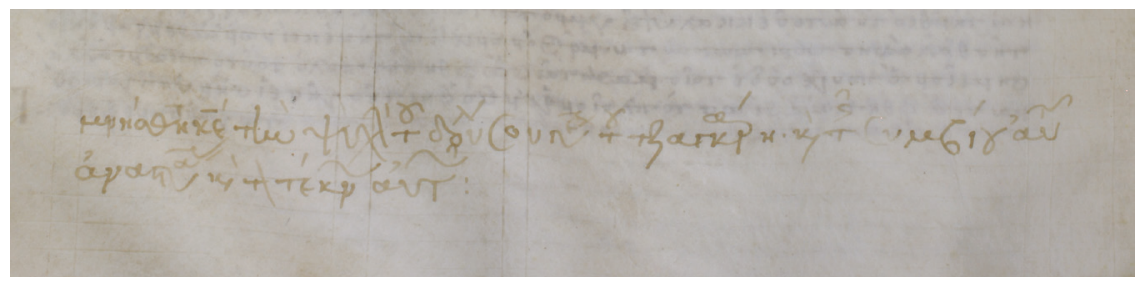

Figure 13. Detail from CBL W 139, 310v

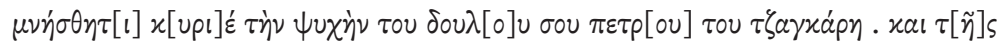

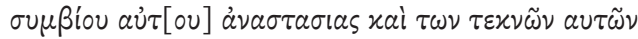

Remember, Lord, the soul of your servant Peter the Shoemaker, and his partner Anastazia and their children.

\section{ReVISITING THE STORY}

Although a "fictional" reconstruction, this story illuminates one way that codices like W 139 may have functioned in their contexts of use, demonstrating how readerly competencies, motivations, and manuscript technology coalesce to create particular reading experiences. ${ }^{42}$ Manuscripts preserve traditional information on the gospels passed on by scribal craftspeople and readers; exploring the ways they function sheds light on the possibilities for producing editions of the gospels in a digital medium and for further research on the efficacy of paratexts. The complexity of manuscripts and the many possible interactions that people might have with them, coupled with a new philological interest in all manuscripts as critically valuable, necessitates new editorial approaches to the manuscript tradition.

The first thing to notice along these lines is that the codex functions like an interpretive network. It preserves not only the gospel text but also multiple crossreferencing and segmentation systems, most of which derive from late antiquity and serve different functions and encourage different reading protocols. ${ }^{43}$ The four systems that intersect on $38 \mathrm{v}$ work in entirely different ways. For example, the

${ }^{42}$ I want to emphasize here that this is one possible reconstruction of a reading of W 139. It is also clear, judging by its developed lection apparatus and synaxarion and menologion lists, that this manuscript was designed to be read regularly in the context of public liturgical services. But other paratexts, like the Eusebian apparatus, gesture also toward other, more "scholarly" and perhaps private reading events. This manuscript lends itself to use in multiple contexts.

${ }^{43}$ See Anthony Grafton and Megan Williams, Christianity and the Transformation of the Book: Origen, Eusebius, and the Library of Caesarea (Cambridge: Belknap Press of Harvard University Press, 2006), 178-249. 
sixty-eight-chapter kephalaia system composed of numbers and titles located in a separate table preceding the text and cross-referenced to headings on the proper folia assist the reader in traversing the artifact, divide the text into literary segments, and give terse notice of the topic of each textual segment, even if the possible interpretations or emphases of the text are more expansive. For example, the title of kephalaion 5, "Regarding the Beatitudes," begins at Matt 5:1 on 38v and runs through the end of the Sermon in Matt 7:29 (48r). The macarisms are a famous and important part of this segment, but the teaching preserved in the sermon contains a much greater quantity of material than the formulaic beatitudes. Kephalaion 6,

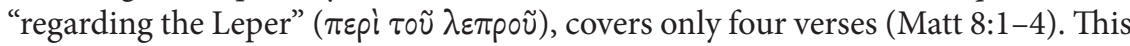
system simultaneously identifies the sermon as a coherent textual segment by refusing to subdivide its content and distills its content to only the first twelve verses of Jesus's first-person speech (Matt 5:1-12).

In contrast, the structure of the Eusebian system breaks up the sermon into its constituent utterances based on the text's relationship to the other canonical gospels. Instead of one chapter, it divides the sermon into thirty-nine sections. Even without navigating to the canon tables at the outset of the artifact $(4 \mathrm{v}-9 \mathrm{r})$, the reader can see that many parts of the sermon are unique to Matthew (canon 10), that the sermon has much overlap with Luke (canon 5), smaller sections of overlap with the Synoptics (canon 2), and one instance each of overlap with Luke and John (canon 3) and with Mark alone (canon 6). The Eusebian system manually hyperlinks small textual segments to perceived equivalents organized through the matrix of the canon tables. The juxtaposition of these systems is a feature common to many late antique and medieval gospel codices. ${ }^{44}$

The recognition of the complexity of these systems and their interrelationships creates an impetus for further editorial endeavors. In an effort to understand how gospel manuscripts, and indeed manuscripts of any literary tradition, function as arbiters of their own texts and trace the development of paratextual systems across time, editors can transcribe and encode the precise deployment of these features in relation to the main text of the manuscript. Most of these features are already able to be encoded in the transcription editor of the New Testament Virtual Manuscript Room (NTVMR), the digital space where editing for the Editio Critica Maior editions occurs. ${ }^{45}$

\footnotetext{
${ }^{44}$ See Stefan Royé, “The Cohesion between the Ammonian-Eusebian Apparatus and the Byzantine Liturgical Pericope System in Tetraevangelion Codices: Stages in the Creation, Establishment and Evolution of Byzantine Codex Forms," in Catalogue of Byzantine Manuscripts in their Liturgical Context: Challenges and Perspectives; Collected Papers, Resulting from the Expert Meeting of the Catalogue of Byzantine Manuscripts Programme Held at PThU in Kampen, the Netherlands on 6th-7th November 2009, ed. Klaas Spronk, Gerard Rouwhorst, and Stefan Royé, Catalogue of Byzantine Manuscripts in their Liturgical Context: Subsidia 1 (Turnhout: Brepols, 2013), 55-116.

${ }^{45}$ See http://ntvmr.uni-muenster.de.
} 
The two-sided problem with this approach is, on the one hand, that editing paratexts is time consuming, extending beyond the text-focused goals of most editions, and, on the other, that New Philology usually focuses on the specificities of individual manuscripts. But we are now in a position to create fuller digital facsimiles that embed hyperlinks between points of cross-reference and to think about ways to aggregate the philological work of this kind into an expanding open edition like the NTVMR that encompasses a significant quantity of manuscripts. For example, lection notations in the margins of a folio can be linked directly to their appearance in the synaxarion list and the Eusebian sections linked to their place in the canon tables. This approach will require the further development of digital editorial tools and partnerships with software engineers and digital humanists, but it is valuable because it maps the competing knowledge networks embedded in the manuscript and facilitates comparison to the deployment of these systems in other witnesses to these systems, providing evidence for a range of critical questions. ${ }^{46}$ This approach to editing documents, even if selective and piecemeal at the outset, supplements textual approaches that seek to reconstruct initial texts, creating editions that contextualize textual editorial decisions in material culture.

The digital editing that I envision could be built upon a series of highly marked-up editions of individual manuscripts, created using the editorial resources that (for the most part) already exist in a communal workspace like the NTVMR, which includes tools like the Transcription Editor and Feature Tags module. This approach will take significant time-after all, the critical editing of the biblical text itself is ongoing even after hundreds of years of sustained effort-and will be constrained by the larger critical questions that editors bring to their task. Nevertheless, there is value in continuing to engage with the New Testament's manuscripts. Perhaps a more sustainable model is to edit various classes of paratexts as modules for a larger-scale open edition, an edition comprising full text transcriptions, manuscript images, and additional paratextual information, where various editors hold responsibility for different forms of metadata. Users could then retain the flexibility to turn on and off different modules based on their interests or toggle between different kinds of initial texts and apparatuses. Within the NTVMR, the modular approach already exists insofar as the site is composed of a series of tools designed by multiple stakeholders that facilitate textual exploration.

This kind of digital editing enables curated manuscript images and paratextual metadata to be embedded in digital editions that focus on textual reconstruction, expanding the critical utility of the classical critical edition. The linking of particular textual segments to feast days and liturgical cycles, for example, is a reservoir of reception that has yet to be explored by biblical scholars because it is not readily available and because no edition of Greek lectionary manuscripts (or continuous

\footnotetext{
${ }^{46}$ Some of this work is already underway in the ParaTexBib project in Munich; see http:// www.paratexbib.eu/.
} 
text manuscripts with lection data) has been produced.$^{47}$ Including this material as an embedded part of a digital edition or as a module available via hyperlink from the main text of an edition facilitates further scholarly engagement with these traditions. Editions are valuable scholarly tools because they abstract relevant information from a great mass of textual material. But with digital editions, we are beginning to have greater access to the "back end" data-images, transcriptions, paratexts. These materials make editions ever more powerful tools, but they also demand more of the users if they are to make the most of what stands behind editorial decisions. Although editions have usually been employed as tools to avoid engaging directly with the manuscripts, manuscript literacy will become a critical skill necessary to engage with emerging digital editions. New philologists in particular will be interested in this enhanced data on various aspects of the New Testament's manuscript tradition.

Because the omnibus of a manuscript's features mediates the text to readers, another possible avenue of research on artifacts such as W 139 that is enabled by their editing is to engage cognitive science and aesthetics. Philologists and editors can reconstruct the intended function of paratexts and extrapolate their potential effects on readers (via thought experiments, for example), but other approaches are needed to begin to analyze how paratexts affect the cognitive process of readers. How do the positioning, aesthetics, content, and scope of paratexts impinge on readers' perceptions, eye movements, and interpretations? Recently, some studies in empirical aesthetics have measured the influence of paratexts such as titles on the interpretation of visual artworks, using eye-tracking tools, surveys, and other quantitative measures of comprehension. ${ }^{48}$ Going further than these focused studies, the possibilities of the complex paratextual systems like those in W 139 indicate that significant space exists for philologists and editors to partner with aestheticians and cognitive scientists to test, if only in preliminary ways, the actual effects of these items on readers in terms of perception and interpretation. There are obstacles to this approach, of course-very few people can read Greek manuscripts or decode the terse and often abbreviated paratexts as they stand in the manuscript.

${ }^{47}$ On this prospect, see Gregory S. Paulson, "A Proposal for a Critical Edition of the Greek New Testament Lectionary," in Liturgy and the Living Text of the New Testament: Papers from the Tenth Birmingham Colloquium on the Textual Criticism of the New Testament, ed. H. A. G. Houghton, TS 3/16 (Piscataway, NJ: Gorgias, 2018), 121-50.

${ }^{48}$ See, e.g., Margery B. Franklin, “Museum of the Mind': An Inquiry into the Titling of Artworks," Metaphor and Symbolic Activity 3.3 (1988): 157-74; Helmut Leder, Claus-Christian Carbon, and Ai-Leen Ripsas, "Entitling Art: Influence of Title Information on Understanding and Appreciation of Paintings," Acta Psychologica 121 (2006): 176-98. Other studies have used paratexts as variables to test the impact of perceived authorial intention on audience appreciation of visual art; see, e.g., Justin L. Barrett, Jean-Luc Jucker, and Rafael Wlodarski. "II Just Don't Get It': Perceived Artists' Intentions Affect Art Evaluation," Empirical Studies of the Arts 32 (2014): 149-82. 
But it is a worthwhile step nonetheless to attempt to square philological perceptions of the significance of these items with their actual cognitive functions-that is, how they direct the mind of readers under various conditions-and what effects they have on readers with different competencies and from different backgrounds. Reading events are defined by the confluence of the manuscript's text, paratexts, and materiality and the reader's capabilities, individual experiences, and other factors.

Regardless of how we engage the paratextuality of manuscripts like CBL W 139, its features that print culture sidelined for a host of legitimate reasons can now be reconnected to editions in the digital realm. ${ }^{49}$ Further, the mass digitization of Greek New Testament manuscripts is now beginning to pay dividends in the form of new kinds of research on the tradition. It is important to include as many peculiarities of the tradition as possible if we are to use editions as a means of understanding not only textual history but also manuscript traditions as cultural history and arbiters of knowledge of the texts they transmit. These are two sides of the same coin, and there is much editorial work yet to be undertaken on the New Testament's manuscripts.

\footnotetext{
${ }^{49}$ Some of the systems in W 139 are also part of the Nestle-Aland editions, like the Epistle to Carpianus and the rest of the Eusebian system, but the totality of its features remain unavailable to users of editions.
}

This publication was made possible through the support of a grant from Templeton Religion Trust. The opinions expressed in this publication are those of the author and do not necessarily reflect the views of Templeton Religion Trust. Research for this publication also received support from the TiNT project, funded by the European Research Council (ERC) under the European Union's Horizon 2020 research and innovation programme (grant agreement No. 847428).
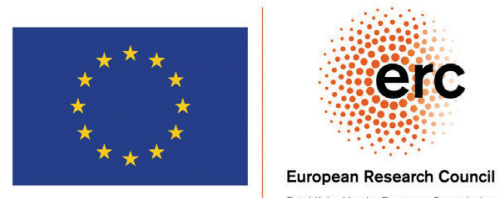

European Research Council Established by the European Commission 